\title{
Insulin sensitivity and $\operatorname{Lp}(\alpha)$ concentrations in normoglycemic offspring of type 2 diabetic parents Agathoklis Psyrogiannis*, Ioannis Habeos and Venetsana Kyriazopoulou
}

Address: Division of Endocrinology and Diabetes, Department of Medicine, University of Patras Medical School, Patras, Greece

Email: Agathoklis Psyrogiannis* - apsirog@med.upatras.gr; Ioannis Habeos - ihabeos@med.upatras.gr;

Venetsana Kyriazopoulou - vkyriazo@med.upatras.gr

* Corresponding author

Published: 29 October 2003

Lipids in Health and Disease 2003, 2:8

This article is available from: http://www.Lipidworld.com/content/2/I/8 all media for any purpose, provided this notice is preserved along with the article's original URL.

Received: 24 September 2003

Accepted: 29 October 2003

\begin{abstract}
Background: Offspring of at least I parent with type 2 diabetes are more resistant to the insulin action, exhibit higher incidence of dyslipidemia and are more prone to cardiovascular diseases. The association between $\operatorname{Lp}(\alpha)$ and coronary heart disease is well established. An association between $L p(\alpha)$ concentration and insulin sensitivity was examined in this study.

We investigated the serum $L P(\alpha)$ in 4 I offspring of 4 I families of type 2 diabetic subjects (group I) with normal glucose tolerance, compared to 49 offspring who their parents had no history of type 2 diabetes, matched for sex, age, BMI, WHR and blood pressure (group II). Serum $L p(\alpha)$, triglycerides, insulin resistant index, HDL, LDL-cholesterol and insulin were measured.
\end{abstract}

Results: The offspring of type 2 diabetic subjects had higher fasting serum triglycerides (mean \pm SD $199.3 \pm 184.2$ vs. $147.1 \pm 67.9 \mathrm{ng} / \mathrm{dl}, \mathrm{p}<0.05)$ lower HDL-cholesterol $(37.3 \pm 9.0$ vs. $44.6 \pm$ $7.8, p<0.00 \mathrm{I})$ and particularly higher Insulin resistance Index (HOMA-IR) $(2.84 \pm 1.39$ vs. $1.67 \pm$ $0.77, \mathrm{p}<0.00 \mathrm{I})$.

They also had higher serum $L P(\alpha)$ concentration ( $15.4 \pm 6.7$ vs. $8.6 \pm 6.0, p<0.001)$. By simple linear analysis in the offspring of type 2 diabetic parents there was no correlation of $\operatorname{Lp}(\alpha)$ concentration with insulin resistance index Homa-IR $(r=0,016 p=N S)$.

Conclusions: We conclude that serum $\operatorname{LP}(\alpha)$ is significantly increased in offspring of type 2 diabetic subjects but was not related to insulin sensitivity.

\section{Background}

Patients with type 2 diabetes mellitus are characterized by resistance to insulin-stimulated glucose uptake $[1,2]$, dyslipidemia (especially increased triglyceride and decreased high-density lipoprotein (HDL) levels [3,4], hypertension [5] and coronary heart disease [6,7].

Lipoprotein $(\alpha)[\operatorname{Lp}(\alpha)]$, first described by Berg [8] in 1963 , is a low density lipoprotein (LDL) - like substance with a specific apoprotein, apoprotein $(\alpha)$ [apo $(\alpha)$ ], bound to apo- $\beta 100$ by disulfide bridges $[9,10]$.

Numerous studies have suggested that lipoprotein $(\alpha)$ concentrations may be an independent risk factor for coronary heart disease [11-15]. However, the molecular mechanism by which $\operatorname{Lp}(\alpha)$ might promote atherosclerosis has not been clarified. 
Table I: Clinical characteristics of the offspring of type 2 diabetes parents (Group I) and offspring of normal parents (Group 2).

\begin{tabular}{lccc}
\hline Parameter & Group I & Group 2 & $\underline{\text { P value }}$ \\
\hline Number (M/F) & $41(28 / 13)$ & $49(31 / 18)$ & NS \\
Age $($ Yr) & $41.4 \pm 6.8$ & $43.5 \pm 5.5$ & NS \\
BMI $\left(K g . \mathrm{m}^{-2}\right)$ & $28.1 \pm 4.8$ & $27.6 \pm 3.5$ & NS \\
WHR & $0.87 \pm 0.1$ & NS \\
Systolic BP $(\mathrm{mmHg})$ & $119.4 \pm 15.5$ & $0.8 \pm 0.08$ & NS \\
Diastolic BP $(\mathrm{mmHg})$ & $72.1 \pm 12.8$ & $120.8 \pm 10.8$ & NS \\
\hline
\end{tabular}

Table 2: Laboratory profile of the offspring of type 2 diabetes parents (Group I) and offspring of normal parents (Group 2).

\begin{tabular}{lccc}
\hline Parameter & Group I & Group 2 & P value \\
\hline Triglyceride $(\mathrm{mg} / \mathrm{dl})$ & $199.3 \pm 184.2$ & $147.1 \pm 67.9$ & $<0.05$ \\
Cholesterol $(\mathrm{mg} / \mathrm{dl})$ & $215.4 \pm 41.6$ & $199.2 \pm 29.8$ & $<0.05$ \\
HDL-cholesterol $(\mathrm{mg} / \mathrm{dl})$ & $37.3 \pm 9.0$ & $44.6 \pm 7.8$ & $<0.001$ \\
LDL-cholesterol $(\mathrm{mg} / \mathrm{dl})$ & $143.7 \pm 31.7$ & $124.6 \pm 25.1$ & $<0.01$ \\
LP $(\alpha)(\mathrm{mg} / \mathrm{dl})$ & $15.4 \pm 6.7$ & $8.6 \pm 6.0$ & $<0.001$ \\
\hline
\end{tabular}

The relationship of $\operatorname{Lp}(\alpha)$ concentrations with insulin resistance remains controversial. Some studies have showed increase $\operatorname{Lp}(\alpha)$ concentration in subjects with NIDDM [16-18] whereas other studies have showed similar $\operatorname{Lp}(\alpha)$ concentrations in type 2 diabetic subjects compared with normoglycemic subjects[19]. In other studies of nondiabetic subjects, insulin concentrations have not been associated with $\operatorname{Lp}(\alpha)$ concentrations [20,21]. One study showed no elevated $\operatorname{Lp}(\alpha)$ concentrations in normoglycemic insulin-resistant subjects [22].

In this report, we examine the association of $\operatorname{Lp}(\alpha)$ concentrations to insulin sensitivity, calculated using the Homeostasis model Assessment (HOMA-IRI) in normoglycemic offspring of at least 1 parent with type 2 diabetes.

\section{Results}

The clinical characteristics of the study population are shown in Table 1 and the laboratory profile of the study population are shown in Table 2.

The group of offspring with type 2 diabetes parents as well as the control group had a similar distribution of age, sex, BMI, WHR systolic and diastolic BP. As expected the mean fasting serum triglycerides, cholesterol, and LDL-cholesterol were significantly higher in group 1 compared to the control group. HDL-cholesterol was significantly lower in group 1 compared to the control group.
The glucose and insulin concentrations in the fasting state and after an oral glucose challenge are shown in Table 3.

The mean fasting glucose and insulin concentrations were significantly higher in group I compared to group 2:

fasting glucose: $4.5 \pm 0.6$ vs. $4.3 \pm 0.6 \mathrm{mmol} / \mathrm{l}(\mathrm{p}<0.05)$

fasting insulin: $14.0 \pm 6.4$ vs. $8.6 \pm 3.2 \mu \mathrm{U} / \mathrm{ml}(\mathrm{p}<0.005)$

Serum insulin concentration 30 min post glucose challenge was significantly higher in the offspring group 1 $(122.2 \pm 94.3$ vs. $81.7 \pm 51.6 \mu \mathrm{U} / \mathrm{ml}, \mathrm{p}<0.005)$ as well at $60 \mathrm{~min}$ post glucose challenge $(134.4 \pm 103.1$ vs. $99.9 \pm$ $48.9 \mu \mathrm{U} / \mathrm{ml}, \mathrm{p}<0.05)$ whereas there was no difference at $120 \mathrm{~min}$.

In the offspring of the diabetic parents the insulin resistance index was significantly higher compared to control group $(2.84 \pm 1.39$ vs. $1.67 \pm 0.77, \mathrm{p}<0.001) .22(53.6 \%)$ of the 41 subjects of group 1, had HOMA-IR values > 2.5 indicating that they were insulin resistant [23-29], compared to only $6(12.2 \%)$ of the 49 subjects of group 2 .

$\operatorname{Lp}(\alpha)$ concentration was significantly higher in group 1 compared to group $2(15.4 \pm 6.7$ vs. $8.6 \pm 6.0 \mathrm{ng} / \mathrm{dl}, \mathrm{p}<$ $0.001)$.

In the offspring of the diabetic parents the insulin resistance index was positively correlated with serum triglycer- 
Table 3: Serum insulin and glucose and insulin resistance index in offspring and control subjects in the fasting state and after an oral glucose challenge (120 min)

\begin{tabular}{|c|c|c|c|}
\hline & Group I no 4I & Group 2 no 49 & $\underline{P}$ value \\
\hline \multicolumn{4}{|l|}{ Glucose (mmol/l) } \\
\hline Fasting & $4.53 \pm 0.62$ & $4.26 \pm 0.56$ & 0.036 \\
\hline $30 \mathrm{~min}$ & $8.4 \pm 2.0$ & $8.3 \pm 1.5$ & NS \\
\hline $60 \mathrm{~min}$ & $8.4 \pm 3.0$ & $8.9 \pm 2.5$ & NS \\
\hline $120 \mathrm{~min}$ & $5.4 \pm 1.3$ & $5.6 \pm 1.2$ & NS \\
\hline \multicolumn{4}{|l|}{ Insulin $(\mu \mathrm{U} / \mathrm{ml})$} \\
\hline Fasting & $14.0 \pm 6.4$ & $8.6 \pm 3.2$ & $<0.001$ \\
\hline $30 \mathrm{~min}$ & $122.2 \pm 94.3$ & $81.7 \pm 50.6$ & 0.013 \\
\hline $60 \mathrm{~min}$ & $134.4 \pm 103.1$ & $99.9 \pm 48.9$ & 0.042 \\
\hline $120 \mathrm{~min}$ & $76.9 \pm 8.1$ & $70.5 \pm 40.7$ & NS \\
\hline $\begin{array}{l}\text { Insulin Resistance Index (HOMA- } \\
\text { IR) }\end{array}$ & $2.84 \pm 1.39$ & $1.67 \pm 0.77$ & $<0.001$ \\
\hline
\end{tabular}

Table 4: Correlation (r) and significance (P) of HOMA-IR with serum concentration of Lipids and $\operatorname{Lp}(\alpha)$.

\begin{tabular}{|c|c|c|c|c|}
\hline \multirow[t]{2}{*}{ Parameter } & \multicolumn{2}{|c|}{ Group I } & \multicolumn{2}{|c|}{ Group 2} \\
\hline & $\mathbf{r}$ & $P$ value & $\mathbf{r}$ & $P$ value \\
\hline Cholesterol & 0.177 & NS & 0.231 & NS \\
\hline Triglycerides & 0.319 & $p<0.01$ & 0.099 & NS \\
\hline $\mathrm{HDL}$ & 0.304 & $p<0.05$ & 0.055 & NS \\
\hline LDL & 0.342 & $p<0.02$ & 0.161 & NS \\
\hline $\operatorname{Lp}(\alpha)$ & 0.016 & NS & & \\
\hline
\end{tabular}

ides and LDL. There was no correlation of HOMA-IR with any of the above parameter in the control group (Table 4).

There was no correlation of HOMA-IR with $\operatorname{Lp}(\alpha)$ concentration in the offspring of the diabetic parents.

\section{Discussion}

Resistance to insulin-stimulated glucose uptake is a characteristic finding in patients with type 2 diabetes $[1,2]$. The observation that concordance for type 2 diabetes approaches $100 \%$ when one identical twin has the disease, strongly suggests that the decisive component of this syndrome is genetic in nature [30]. Several studies have shown that offspring of at least one parent with type 2 diabetes display hyperinsulinism and are more resistant to insulin action than offspring of parents whose glucose tolerance was normal [31-34].

The result of our study supports and expands those findings. We found that offspring of patients with type 2 diabetes when compared with normal individuals whom their parents had no history of type 2 diabetes matched for sex, age and BMI, were relative hyperinsulinemic, had higher fasting serum triglycerides, lower HDL-cholesterol and higher insulin resistance index.

Moreover, the serum $\operatorname{Lp}(\alpha)$ concentration was significantly higher compared with control group. The overall impression from the large number of publications on diabetes mellitus and $\operatorname{Lp}(\alpha)$, is that neither insulin dependent nor non-insulin dependent diabetes has a direct effect on serum $\operatorname{Lp}(\alpha)$ [16-19,31-34]. Some reports of increased levels in non-insulin dependent diabetes may result from the inclusion of patients with established $\mathrm{CHD}$ in the population studied. However, there does appear to be an increase in serum $\operatorname{Lp}(\alpha)$ in insulindependent diabetes when nephropathy is present and this may be the case even when this is at the stage of microalbuminuria [35-42]. Thus the rise seems to occur with much less marked proteinuria than in primary renal disease. Possibly this is because there is some specific feature of the nephropathy in diabetes, which triggers the $\operatorname{Lp}(\alpha)$ response early in the disease or perhaps microalbuminuria in diabetes is a marker for a more extensive vasculopathy which is the major stimulus for $\operatorname{Lp}(\alpha)$ to increase. 
There has been little published data on insulin sensitivity and $\operatorname{Lp}(\alpha)$ concentrations. $\operatorname{Lp}(\alpha)$ concentrations were not significantly related to insulin sensitivity measured by the intravenous glucose tolerance test in nondiabetic subjects [43]. Haffner et al [22] demonstrated that insulin-resistant normoglycemic men did not have elevated $\operatorname{Lp}(\alpha)$ concentrations and that $\operatorname{Lp}(\alpha)$ concentrations are principally controlled at the locus encoding apo $(\alpha)$ in agreement with the data of other studies [44-47].

Moreover, Haffner et al suggested that the relationship between insulin sensitivity and $\operatorname{Lp}(\alpha)$ concentrations might be at least partially dependent on apo $(\alpha)$ phenotype [22]. One possibility for such an association could be that genes for apo $(\alpha)$ genotype and insulin sensitivity could be in linkage disequilibrium.

To our knowledge this is the first report in which the levels of $\operatorname{Lp}(\alpha)$ concentration and insulin sensitivity in normoglycemic offspring of type 2 diabetic parents were studied. Our study demonstrates that $\operatorname{Lp}(\alpha)$ concentrations were not significantly correlated with HOMA-IR $(r=0.016)$. The impression from this finding and in agreement with previous studies $[16,19-21,35-43]$, is that serum $\operatorname{Lp}(\alpha)$ concentration is not related to insulin sensitivity. However, $\operatorname{Lp}(\alpha)$ concentration was significantly higher in the group of offspring of diabetic parents compared to the control group $(\mathrm{p}<0.001)$

\section{Conclusions}

We conclude that serum $\operatorname{LP}(\alpha)$ is significantly increased in offspring of type 2 diabetic subjects but was not related to insulin sensitivity.

\section{Methods \\ Subjects}

We studied 54 healthy offspring of 54 separate families with type 2 diabetes parents. The subjects were Caucasians of Greek origin. They all had a parent who had developed type 2 diabetes mellitus after 50 years of age. Two patients were the offspring whom both parents were diabetic. Maturity-onset diabetes of the young was excluded on the basis of the late onset of diabetes. The 54 subjects (group 1) were matched to 54 subjects with no family history for diabetes and were used 95 controls (group 2). The subjects in both groups were matched for sex, age, Body Mass Index (BMI) and waist-to-hip ratio (WHR).

All subjects had normal physical examination and normal values for routine laboratory parameters including hematology, c-reactive protein, HbA1c (upper limit of normal $6.5 \%)$, adrenal, kidney, liver and thyroid function. The subjects were not under any medication known to affect carbohydrate or lipoprotein metabolism and all denied alcohol intake.
After an appropriate carbohydrate diet for one week, an oral Glucose Tolerance test (OGTT) was performed and patients with impaired glucose tolerance or type 2 diabetes were excluded from the study. Forty one subjects remained for group 1 and 49 for group 2. Informed consent was obtained from all participants in the study.

\section{Study design}

After 12-h overnight fast, blood samples were drawn for serum glucose, insulin, lipids, lipoprotein and $\operatorname{Lp}(\alpha)$. The subjects then ingested $75 \mathrm{~g}$ of glucose load over a 2-min period. Blood samples were drawn at 30,60 and $120 \mathrm{~min}$ thereafter for measurement of serum glucose and insulin concentrations. Plasma glucose was measured with an automatic analyzer by the glucose oxidase method. Immunoreactive insulin (IRI) was measured with an insulin radioimmunoassay (RIA) kit.

We used the homeastatic model to assess insulin resistance, where HOMA-IR = fasting plasma insulin $(\mu \mathrm{U} / \mathrm{ml}) \times$ fasting plasma glucose (mmol/l) / 22.5 [23-25]. HOMAIR provides a reliable estimate of insulin resistance across the range of glucose tolerance using either the frequently sampled intravenous glucose tolerance test (FSIGTT) with minimal model analysis or the glucose clamp technique as the gold standard measure of insulin sensitivity $[26,27]$.

Total serum cholesterol, serum triglyceride and HDL-cholesterol were assayed with a commercial kit (Boehringer Mannheim, Germany). LDL cholesterol was calculated according to the Friedewald education [28]. $\operatorname{Lp}(\alpha)$ was estimated by enzyme immunoassay (Macra $\operatorname{Lp}(\alpha)$, Strategic Diagnostic, Newark, NJ).

The study design was approved by the ethical and scientific committee of the Hospital.

\section{Statistical analysis}

Results are expressed as mean \pm SD. Data were analyzed according to the unpaired student's t-test or by the nonparametric Mann-Whitney U test of Wilcoxon's test. Pearson's correlation coefficient or the Spearn's test were used depending on the normal distribution of the variables. A p-value of less than $5 \%$ was considered statistically significant.

\section{References}

I. Reaven GM: Insulin resistance in non-insulin dependent diabetes mellitus does it exist and can it be measured? Am J Med I983, Suppl I A:3-I7.

2. De Fronzo RA, Bonadonna RC and Ferrannini E: Pathogenesis of NIDDM: a balanced overview. Diabetes Care 1999, I 5:3 I8-368.

3. Garg A, Helderman JH, Koffler M, Ayuso R, Rosenstock J and Raskin $P$ : Relationship between lipoprotein levels and in vivo insulin action in normal white men. Metabolism 1988, 37:982-987.

4. Mykkanen L, Haffner SM, Ronnemaa L, Lehto S, Ronnemaa T, Pyorala $\mathrm{K}$ and Laakso $\mathrm{M}$ : Is there a sex difference in the association of 
insulin levels and insulin sensitivity with lipids and lipoproteins? Metabolism 1994, 43:523-528.

5. Ferrannini E, Buzzigoli G, Bonadonna R, Giorico MA, Oleggini M, Graziadei L, Pedrinelli R, Brandi $L$ and Bevilacqua S: Insulin resistance in essential hypertension. $N$ Engl J Med 1987, 3 I 7:350-357.

6. Pyorala K, Savolainen E, Kaukola S and Haapakoski J: Plasma insulin as coronary heart disease risk factor: relationship to other risk factors and predictive value during $9^{1 / 2}$ year follow-up of the Helsinki Policeman population. Acta Med Scand 1985, 70 I (Suppl):38-52.

7. Ducimetiere P, Eschwege E, Papoz L, Richard JL, Claude JR and Rosselin G: Relationship of plasma insulin levels to the incidence of myocardial infarction and coronary heart disease mortality in middle-aged population. Diabetologia 1980, 19:205-210.

8. Berg K: A new serum type system in man - The Lp system. Acta Pathol Microbiol Scand 1963, 59:369-382.

9. Utermann G: The mysteries of lipoprotein (a). Science 1989, 246:904-910.

10. Scann AM and Fress GM: Heterogeneity and biological relevance. / Clin Invest 1990, 85: I709-1715.

II. Berg K, Dahlen G and Frick $M H$ : $\mathbf{L p}(\alpha)$ lipoprotein and pre-beta lipoprotein in patients with coronary heart disease. Clin Genet 1974, 6:230-235.

12. Dahlen GH, Guyton JR, Attar M, Farmer JA, Kautz JA and Gotto AM $\mathrm{Jr}$ : Association of levels of lipoprotein $\operatorname{LP}(\alpha)$, plasma lipids and other lipoproteins with coronary artery disease documented by angiography. Circulation 1986, 74:758-765.

13. Sandholzer C, Boerwinkle E, Saha N, Tong MC and Utermann G: Apolipoprotein $(\alpha)$ phenotypes $\operatorname{Lp}(\alpha)$ concentration and plasma lipid levels in relation to coronary heart disease in a Chinese population: Evidence for the role of the Apo $(\alpha)$ Gene in Coronary Heart Disease. J Clin Invest 1992 89:1040-1046.

14. Sandholzer C, Saha N, Kark JD, Rees A, Jaross W, Dieplinger H, Hoppichler $F$, Boerwinkle $E$ and Utermann G: Apo $(\alpha)$ isoforms predict risk for Coronary Heart Disease. A study in six populations. Arteriosclerosis Thromb 1992, 12:1214-1226.

15. Mohan V, Deepa R, Haranath SP, Premalatha G, Rema M, Sastry NG and Enas EA: Lipoprotein $(\alpha)$ is an Independent Risk Factor for Coronary Artery Disease in NIDDM Patients in South India. Diabetes Care 1998, 21:1819-1823.

16. Ramirez LC, Arauz-Pacheco C, Lackner C, Albright G, Adams BV and Raskin P: Lipoprotein $(\alpha)$ levels in diabetes mellitus: relationship to metabolic control. Ann Intern Med 1992, I 17:42-47.

17. Ishida $Y$, Kazumi $T$ and Yoshida M: Serum lipoprotein $(\alpha)$ in patients with non-insulin-dependent diabetes mellitus (Abstract). Diabetes 199I, 40(SuppI I): I88A.

18. Heller FR, Jamart J, Honore P, Derue G, Novik V, Galanti L, Parfonry A, Hondekijn JC and Buysschaert M: Serum lipoprotein $(\alpha)$ in patients with diabetes mellitus. Diabetes Care 1993, 16:819-823.

9. Haffner SM, Morales PA, Stern MP and Gruber MK: $\operatorname{Lp}(\alpha)$ concentrations in NIDDM. Diabetes 1992, $41: 1267-1272$.

20. Sundell IB, Nilsson TK, Hallmans G, Hellsten G and Dahlen GH: Interrelations between plasma levels of plasminogen activator inhibitor, tissue plasminoger activator, lipoprotein $(\alpha)$, and established cardiovascular risk factors in a North Swedish population. Atherosclerosis 1989, 80:9-16.

21. Haffner SM, Gruber KK, Morales PA, Hazuda HP, Valdez RA, Mitchell BD and Stern MP: Lipoprotein $(\alpha)$ concentrations in Mexican Americans and non-Hispanic whites: The San Antonio Heart Study. Am J Epidemiol 1992, 136:1060-1068.

22. Haffner SM, Karhapaa P, Rainwater DL, Mykkanen L, Aldrete G Jr and Laakso M: Insulin sensitivity and $L p(\alpha)$ concentrations in Normoglycemic men. Diabetes Care 1995, 18:193-199.

23. Matthews DR, Hosker JP, Rudenski AS, Naylor BA, Treacher DF and Turner RC: Homeostasis model assessment: insulin resistance and b-cell function from fasting plasma glucose and insulin concentrations in man. Diabetologia 1985, 28:412-4I9.

24. Haffner SM, Kennedy E, Gonzalez C, Stern MP and Miettinen H: A prospective analysis of the HOMA model: the Mexico City Diabetes Study. Diabetes Care 1996, 19: I I38-1 I 46.

25. Duncan MH, Singh BM, Wise PH, Carter G and Alaghband-Zadeh J: A single measure of insulin resistance in human disease. Lancet 1995, 346: I20-121.

26. Duncan $M H$, Singh BM, Wise PH, Carter $G$ and Alaghband-Zadeh J: Ability of alternative indices of insulin sensitivity to predict cardiovascular risk: comparison with the "minimal model". Insulin Resistance Atherosclerosis (IRAS) Investigators. Ann Epidemiol 1998, 8:358-369.

27. Bonora E, Targher G, Alberiche M, Bonadonna RC, Saggiani F, Zenere $M B$, Monauni T and Muggeo M: Homeostasis model assessment closely mirrows the glucose clamp technique in the assessment of insulin sensitivity. Diabetes Care 2000, 23:57-63.

28. Friedewald WT, Lery RI and Fredrickson DS: Estimation of the concentration of low density lipoprotein cholesterol in plasma without use of the preparative ultracentrifuge. Clin Chem 1972, 18:499-502.

29. Taniguchi A, Fukushima M, Sakai M, Miwa K, Makita T, Nagata I, Nagasaka S, Doi K, Okumura T, Fukuda A, Kishimoto H, Fukuda T, Nakaishi $S$, Tokuyama $K$ and Nakai $Y$ : Remnant-like particle cholesterol, triglycerides and insulin resistance in nonobese Japanese type 2 diabetic patients. Diabetes Care 2000, 23:1766-1769.

30. Barnett $A H$, Eff $C$, Leslie RD and Pyke DA: Diabetes in identical twins: A study of 200 pairs. Diabetologia 198I, 20:87-93.

31. Ho LT, Chang ZY, Wang JT, Li SH, Liu YF, Chen YD and Reaven GM Insulin insensitivity in offspring of parents with type 2 diabetes mellitus. Diabetic Medicine 1990, 7:31-34.

32. Ganesh RDG, Volkmann A and Leslie HP et al.: Insensitivity to insulin in offspring of non-insulin dependent diabetic patients. Diabetes Nutrition Metabolism 1988, 3:235-237.

33. Haffner SM, Stern MP, Hazuda HP, Mitchell BD and Patterson JK. Increased insulin concentrations in non-diabetic offspring of diabetic parents. $N$ Engl J Med 1988, 3 I9:|297-I30I.

34. Leslie RD, Volkmann HP, Poncher M, Hanning I, Orskov H and Alberti KG: Metabolic abnormalities in children of non-insulin dependent diabetics. Brit Med J 1986, 293:840-84।.

35. Haffner SM, Tattle KR and Rainwater DL: Decrease of lipoprotein $(\alpha)$ with improved glycemic control in IDDM subjects. Diabetes Care 1991, 14:302-307.

36. Kapelrud H, Bangstad HJ, Dahl-Jorgensen K, Berg K and Hanssen KF: Serum $L p(\alpha)$ lipoprotein concentrations in insulin dependent diabetic patients with microalbuminuria. Brit Med. J [99 |, 3:675-678.

37. Levutsky LL, Scanu AM and Gould SH: Lipoprotein $(\alpha)$ levels in black and white children and adolescents with IDDM. Diabetes Care 1991:283-287.

38. Nakata $\mathrm{H}$, Horita $\mathrm{K}$ and Eto $\mathrm{M}$ : Alteration of lipoprotein $(\alpha)$ concentration with glycaemic control in non-insulin dependent diabetic subjects without complications. Metabolism 1993:1323-1326.

39. Ritter MM, Loscar M, Richter WO and Schwandt P: Lipoprotein $(\alpha)$ in diabetes mellitus. Clinica Chimica Acta 1993, 4:45-54.

40. Winocour PH, Bhatnagar D, Ishola M, Arrol S and Durrington PN: Lipoprotein $(\alpha)$ and microvascular disease in type I (insulin dependent) diabetes mellitus. Diabetic Medicine 1991:922-927.

41. Winocour PH, Durrington PN, Bhatnagar D, Mbewu AD, Ishola M, Mackness M and Arrol S: A cross-sectional evaluation of cardiovascular risk factors in coronary heart disease associated with type I (insulin dependent) diabetes mellitus. Diabetes Research and Clinical Practice 1992, 8: 173-184.

42. Wolffenbuttel BH, Leurs PB, Sels JP, Rondas-Colbers GJ, Menheere PP and Nieuwenhuijzen Kruseman AC: Improved blood glucose control by insulin therapy in type 2 diabetic patients has no effect on lipoprotein $(\alpha)$ levels. Diabetic Medicine 1993, 10:427-430

43. Sidhu M, Crook D, Godsland IF, Walton C, Wynn V and Oliver MF: Inverse relationship between $\operatorname{Lp}(\alpha)$ levels and first-phase insulin secretion. Diabetes 1992, 41:134|-1345.

44. Utermann G, Menzel HJ, Kraft HG, Duba HC, Kemmler HG and Seitz C: $\operatorname{Lp}(\alpha)$ glycoprotein phenotypes:inheritance and relation of $\mathbf{L}(\alpha)$ - lipoprotein concentrations in plasma. J Clin Invest 1987, 80:458-465.

45. Rainwater DL, Manis GS and Vandeberg JL: Hereditary and dietary effects on apolipoprotein $(\alpha)$ isoforms and $\operatorname{Lp}(\alpha)$ in baboons. J Lipid Res 1989, 30:549-558.

46. Boerwinkle E, Leffert CC, Lin J, Lackner C, Chiesa $\mathrm{G}$ and Hobbs HH: Apolipoprotein $(\alpha)$ gene accounts for greater than $90 \%$ of the variation in plasma lipoprotein $(\alpha)$ concentrations. J Clin Invest 1992, 90:52-60.

47. Gaubatz JW, Ghanem KI, Guevara J Jr, Nava ML, Patsch W and Morrisett JD: Polymorphic forms of human apolipoprotein $(\alpha)$ : 
inheritance and relationship of their molecular weights to plasma levels of lipoprotein $(\alpha)$. J Lipid Res 1990, 31:603-6.

Publish with Bio Med Central and every scientist can read your work free of charge

"BioMed Central will be the most significant development for disseminating the results of biomedical research in our lifetime. " Sir Paul Nurse, Cancer Research UK

Your research papers will be:

- available free of charge to the entire biomedical community

- peer reviewed and published immediately upon acceptance

- cited in PubMed and archived on PubMed Central

- yours - you keep the copyright

Submit your manuscript here:

http://www.biomedcentral.com/info/publishing_adv.asp 